\title{
Antimalarial chloroquine indicated for viral infections: myth ou hope?
}

\author{
Cloroquina relacionada a malária e sua promissora aplicação como tratamento contra a COVID-19
}

Cloroquina relacionada con la malaria y sus prometedoras aplicaciones para el tratamiento con

COVID-19

Guilherme Marinho Sampaio ORCID: https://orcid.org/0000-0003-4441-7601

Faculdade de Odontologia do Recife, Brazil

E-mail: guilhermemarinhosampaio@ hotmail.com

Gabriel Henrique Queiroz Oliveira

ORCID: https://orcid.org/0000-0002-7795-3964

Faculdade de Odontologia do Recife, Brazil

E-mail: qgabriel116@gmail.com

Hadassa Fonsêca Silva

ORCID: https://orcid.org/0000-0002-9432-9522

Faculdade de Odontologia do Recife, Brazil

E-mail: hadassafonseca1@gmail.com

Alice Pinho André Gomes Morais

ORCID: https://orcid.org/0000-0001-9008-4196

Faculdade de Odontologia do Recife, Brazil E-mail: alicepinho@globo.com

Jatiacynan Andrade Souza

ORCID: https://orcid.org/0000-0002-0863-6260 Faculdade de Odontologia do Recife, Brazil

E-mail: drajatiacynan@gmail.com

William José Lopes Freitas

ORCID: https://orcid.org/0000-0003-1020-2653

Faculdade de Odontologia do Recife, Brazil

E-mail: williamlfreitas@hotmail.com

Paulo Melo Júnior

ORCID: https://orcid.org/0000-0001-9926-5348

Faculdade de Odontologia do Recife, Brazil

E-mail: paulo.reis@upe.br

Sandra Sayão Maia

ORCID: https://orcid.org/0000-0001-6808-9775

Faculdade de Odontologia do Recife, Brazil

E-mail: sandrinhasayao@hotmail.com

João Henrique Santos Silva

ORCID: https://orcid.org/0000-0001-9707-2657

Faculdade de Odontologia do Recife, Brazil

E-mail: santosjoao2105@gmail.com

Juliana Mariano Carvalho Azevedo

ORCID: https://orcid.org/0000-0003-2281-1026

Faculdade de Odontologia do Recife, Brazil

E-mail: julianaazevedo5522@gmail.com

Rodolfo Scavuzzi Carneiro Cunha

ORCID: https://orcid.org/0000-0001-7110-848X

Faculdade de Odontologia do Recife, Brazil

E-mail: scavuzzi@gmail.com

Sheyla Priscila Madeira Melo

ORCID: https://orcid.org/0000-0001-5380-6372

Faculdade de Odontologia do Recife, Brazil

E-mail: sheyla.melo98@gmail.com

Luisa Manuela Pomba Samba

ORCID: https://orcid.org/0000-0002-2482-9791

Faculdade de Odontologia do Recife, Brazil

E-mail: luisapombal22@gmail.com

Caroline Isabele Félix Muniz

ORCID: https://orcid.org/0000-0002-9234-5406

Faculdade de Odontologia do Recife, Brazil

E-mail: carolineisabelle1@ hotmail.com 


\begin{abstract}
Aim: this article describes the use of chloroquine as an antimalarial agent with potential antivirotic indications for COVID-19 infections. Methods: On line searches and gray literature have been used in the construction of this articles, whose database include PUBMED Central, BVS/BIREME, Web of Science, Science Direct, Higher Level Personnel Improvement Coordinator (CAPES), Periodic Door (Portal de Periódicos da CAPES, The Cochrane Library and PROSPERO). Results: chloroquine and hydroxychloroquine has shown appropriate clinical reports when associated with the antibiotic Azithromycin. It has been authorized for the clinical treatment of grave acute forms of COVID infections by countries like Brazil and USA. Conclusions: Chloroquine seems to have potential antivirotic properties that may be useful in the treatment of the grave acute forms of COVID-19 associated with Azithromycin. Nevertheless, Its indication must include ECG monitoring due to the risk of cardiac QT prolongation able to cause sudden deaths.
\end{abstract}

Keywords: COVID-19; Chloroquine; Hydroxychloroquine.

\begin{abstract}
Resumo
Objetivo: este artigo descreve o uso de cloroquina como agente antimalárico com potenciais indicações antiviróticas para infecções por COVID-19. Métodos: Pesquisas on-line e literatura cinza foram utilizadas na construção deste artigo, cuja base de dados inclui PUBMED Central, BVS / BIREME, Web of Science, Science Direct, Portal de Periódicos da CAPES, Biblioteca Cochrane e PROSPERO. Resultados: a cloroquina e a hidroxicloroquina apresentam relatos clínicos adequados quando associados ao antibiótico Azitromicina. Foi autorizado para o tratamento clínico de formas agudas graves de infecções por COVID em países como Brasil e EUA. Conclusões: A cloroquina parece ter propriedades antiviróticas potenciais que podem ser úteis no tratamento das formas agudas graves de COVID-19 associadas à azitromicina. No entanto, sua indicação deve incluir a monitoração de ECG devido ao risco de prolongamento do intervalo QT cardíaco capaz de causar morte súbita.
\end{abstract}

Palavras-chave: COVID-19; Cloroquina; Hidroxicloroquina.

\title{
Resumen
}

Objetivo: este artículo describe el uso de la cloroquina como agente antipalúdico con posibles indicaciones antivirus para las infecciones por COVID-19. Métodos: En la construcción de estos artículos se han utilizado búsquedas en línea y literatura gris, cuya base de datos incluye PUBMED Central, BVS / BIREME, Web of Science, Science Direct, Higher Level Personnel Improvement Coordinator (CAPES), The Cochrane Library y PROSPERO. Resultados: la cloroquina y la hidroxicloroquina han mostrado informes clínicos apropiados cuando se asocian con el antibiótico azitromicina. Ha sido autorizado para el tratamiento clínico de formas agudas graves de infecciones por COVID por países como Brasil y EE. UU. Conclusiones: La cloroquina parece tener propiedades antivirales potenciales que pueden ser útiles en el tratamiento de formas agudas graves de COVID-19 asociadas con azitromicina. No obstante, su indicación debe incluir la monitorización ECG debido al riesgo de prolongación del QT cardíaco capaz de provocar muertes súbitas.

Palabras clave: COVID-19; Cloroquina; Hidroxicloroquina.

\section{Introduction}

Chloroquine has been known to humans for a considerable time period. Reports describing the use of the Chincona officinalis, the plant that originated this drug appeared in Peru, used mainly as teas and medicine; indicated for fever and infections. The latest report from it traces back to 1633 (Fern, 2020).

Later on, chloroquine had its rise during the emergence of World War II, it was experimented for malaria treatment basically, especially in Africa where millions of people die from this disease every year (Foye, 1995). In this sense, the main scientific references regarding chloroquine come from decades ago, as can be observed through the text of this article. In modern times however, constant searches for medicines, insecticides and vaccines take place everyday in order to combat protozoan diseases (Bruce-Chwatt, 1988). 
The follow up of this article went back to 1918, right after World War I, more specifically in the rise of the last worldwide pandemic: the Spanish flu. In that time, the drug which preceded chloroquine, quinine, was first isolated. It began to be used in humans, but was too toxic; and therefore was virtually forgotten. Later on, for military matters in the rise of Nazism in 1934, chloroquine was unofficially discovered by Hans Andersaq and collaborators, who formulated the drug with the brand "Resochin", developed and produced by Beyer laboratories (Krafts, 2012); but was still very toxic with many side-effects, and therefore researched continued taking place until a similar drug was reached: 3-methyl-chloroquine, named Sontochin, already in the 1942, in plain World War II. As the war went on, and with the arrival of the allied forces in Tunisia to combat general Erwin Rommel's troops in the north of Africa, Santochin fell in the North-American hands who quickly sent it to be analyzed, rediscovering chloroquine which quickly began to be used as anti-malarial agent for the soldiers. Therefore, in 1947, chloroquine entered in clinical practice as anti-malarial agent (Sneader, 2005). Later on, during the fifties, chloroquine was in plain use for the chemotherapy of malaria, as well as its main congeners: primaquine and quinine used in combination with dihydropholate reductase inhibitors, especially pyrimethamine which was considered at that time the most appropriate choice associated with sulfonamides and tetracycline (Orolkovas, 1975).

Nearly one century after the Spanish flu, who left hundreds of million deaths all over the world, COVID-19 pandemic started its devastation throughout the world. The disease was introduced to the world on the last day of the year 2019 , cause by SARS-CoV-2; the newly born coronavirus type 2 . The infection was first registered in Wuhan, China, on December $1^{\text {st }} 2019$ (OMS, 2020; International Health Regulations Emergency Committee, 2019). The virus was then immediately believe to be related to zoonotic origins due to the proximity to the seafood market of Wuhan, where living animals of different sorts were freely sold for human consumption (BJ News. 2020; Novel Coronavirus Pneumonia Emergency Response Epidemiology Team, 2020).

The aim of this review article was to research in the current literature if chloroquine use for COVID-19 treatment is a myth, or can be indeed a promising clinical approach for the treatment of the pandemic.

\section{Literature Review}

\section{The biology of the malarial infection}

Malarial biology is related to five regular species of intracellular protozoa from the gender Plasmodium. It reproduces asexually when infect humans, while, on the other hand, reproduces sexually in females transmitting vector mosquitos, belonging to the Anopheles genus (Inder, 1973). Each species has specific morphological features corresponding to the symptoms related to each one of them; which are: Plasmodium falciparum (1) responsible for malignant 48-hour malaria, regarded by clinical practitioners as the most dangerous form of human malaria. In non-immunized individuals, it often produces a fulminant infection which may be most certainly fatal, if not properly treated. That is why waiting for parasitemia proof is senseless, since the delay may promote an irreversible state of shock, even if the peripheral circulating blood is no longer infected (Verveeck, 2005).

The second species, Plasmodium vivax (2), produces a benign 48 hour form of malaria, with milder clinical symptomatology and with a lower mortality rate. However; traces of the infection may take place following two or more years of the primary infection. In the sequence, Plasmodium ovale (3) shows a peculiar characteristic: it produces rare malaria infections whose recurrences are similar to the ones of Plasmodium vivax, although milder and easily treatable. On the other hand, Plasmodium malariae (4) produces the 72 hour malaria, commonly found in specific tropical areas. The manifestations many times happen years after the first infections had been reported, although rarer than in the cases of P. vivax infections (Verbeeck, 2005) (5). 
The treatment of malaria became virtually restricted to these species of Plasmodiums. However another one was discovered in long-tailed and pig-tailed macaques from Malasia: Plasmodium knowlesi. Although believed to infect only monkeys, its infections speeded through southeast Asia affecting thousands of people in less than 2 years. In this way, a great number of the human infectious diseases went undiagnosed until the emergence of molecular detection techniques, opening then a new era for the appropriate forms of treatment (White, 2008).

Malaria are usually vectorially transmitted through sporozoites injected in the blood stream by the bite of infected female mosquitos, but can also be acquired by blood transfusion from bearers of the disease. Once the parasites reach the blood stream, they are transported to the hepatic parenchyma, where they are located to multiply and develop. In this tissue state they are named schizontes, and are asymptomatic, lasting from 5 to 15 days in average, depending on the species of plasmodium.

The schizontes located within the tissues breakdown the hepatocytes that imprison them and immediately unleash thousand of merozoites, which enter the bloodstream and take over the erythrocytes, invading them. By this time they initiate the erythrocyte phage of the infection, and the parasites no longer need to invade any other tissues. Afterwards they develop asexually and become mature schizontes; the erythrocytes end up breaking and liberating, each one, from 6 to 24 merozoites, causing intense fever and asthenia. The liberated mereroites then infect other erythrocytes continuing the cycle, until they finally cause the death of the host, or until they are terminated by the action of the adaptive immunity (Steck, 1971). To guarantee the survival of the species, some parasites differ into sexual forms of gametocytes to be ingested by the anopheline mosquito, followed by gametogenesis and fertilization of the female gametocyte, within its digestive tract forming a zygoite, in the form of oocysts which originate the infecting for that invades and is located in the salivary gland of the mosquito, which continues infecting humans by exerting hematophagy biting (Organización Mundial de la Salud, 1964).

Once erythrocyte is infected, its duration depends strictly on the kind of species of plasmodium responsible. In this sense, P. knowlesi shows the shortest cycle of all; around 24 hours. Following the time period, P. vivax, P. falciparum and P. ovale, have intermediary cycles of 48 hours, while the longest cycle belongs to $\mathrm{P}$ malaria, which is virtually 72 hours (Gamham, 1966).

\section{Chloroquine and its congeners}

The chemistry of chloroquine and all the drugs deriving from it is categorized as a large series of 4-amino-quinolines, which have been researched in the antimalarial program of USA in the middle of World Was II, with virtually 75 years of clinical practice. From all that side effects that have appeared since this period, chloroquine can be considered relatively secure, due to decades of clinical use (Wallace, 1994). However; in the first years that it was put into massive military use, the American program concluded that it was necessary to develop new drugs from quinacrine, an acridine derivative that was no longer used for the chemical treatment of malaria, and which would be less toxic and much more effective (Rynes, 1998). Although the Russians had described the 4-aminoquinolins as potential antimalarials, they were not taken seriously until the French researchers officially reported that 4- diethylamino-1-methylbutylamino quinoline, an official medicine labeled SONTOCHIN, had been proved as well tolerated with greater activity in human malaria (Peters, 1970). From this tuning point, in 1943, a vast number of compounds became to be commercialized and tested as possible candidates for anti-malarial treatment in mammals and to assess toxicity, but in birds. From them all, chloroquine became undoubtfully the best one, and was released for clinical trials. With the end of the war, chloroquine, under the name of RESOCHIN, being available as a white diphosphate powder was considered stable in solutions (Rockwell, 1978).

Chloroquine has very similar chemical characteristics as quinacrine. Forn instance, it has the same alkyl lateral chain, which differs only by having a quinoline nucleus instead of acridine, with no methoxy radical. Obviously as it seems, chloroquine has got much resemblance to paquine and pentaquin, previous drugs abandoned for being too toxic, and differs 
from them because of the position of the alkyl lateral chain, as well as for having a chlorine atom in place of the nucleus methoxy radical (Pinder, 1973). Chloroquine chemical forms d, 1 as well as $\mathrm{dl}$ were just indistinguishable in potency trials accomplished in duck malaria. Its isomer $d$ is regarded as slightly less toxic than the 1 isomer, present in mammals. The details of the relationship between chloroquine structure and activity were discussed by Berliner et al. in 1948.

\section{Pharmacological effects}

Although chloroquine had been developed initially as an anti-malarial, it has many other pharmacological indications. It is also indicated for the treatment of amoebiasis (Powell, 1971). Because of its outstanding anti-inflammatory features it has also been prescribed for rheumatoid arthritis (Bagnal, 1957) and also for discoid and systemic lupus erythematous (Rainsford, 2015); although for this latter there have been controversial oppinions (Dubois, 1978). Chloroquine has also been indicated for photo allergic reactions, such as late cutaneous porphyria and solar urticaria. Polymorphic eruption has also responded well; although higher doses are necessary than for malaria, requiring weighting and precaution for calculating the risk/benefit ratio compared to its toxicity (Isaacson, 1982).

As for what regards antimalarial properties, some limitations concerning chloroquine indication have been detected. It has been found that chloroquine does not have significant activity against plasmodium exoerythrocyte phases within the diverse tissues, even if applied in massive doses. Therefore it is not indicated to prevent the establishment of malaria. It is, however, effective against the erythrocyte forms of P. vivax and falciparum, as well as for P. vivax gametocytes. In case of acute infections, chloroquine quickly diminishes the clinical symptoms and the replication of the parasite, and the patients become apyretic usually within 24 up to 48 hours following the administration of the doses; and the peripheral blood is usually negative in these cases, when compared parasites after 48 to 72 hours of clinical administration (Carlson, 1990; Rowe, 1995; Udomsangpetch, 1995).

\section{Antimalarial mechanism of action.}

In spite of the fact that chloroquine causes effects on the organism, it seems to be combined with the primary mechanism of plasmodicidal action, although this process is not very clear. It was initially figured that the mechanism had something to do with the DNA of the cell. The work accomplished by Schellemberg and Coatney (1960), concluded that chloroquine was able to inhibit the incorporation and integration of P32-labeled phosphate into RNA and DNA by P. gallinaceumin, both in vitro and in vivo. Further still, it was proved that the drug inhibited persistently DNA polymerase as well as RNA polymerase, although to a lesser extent (Cohen, 1965); but in both cases it happened in combination with a DNA model (Allison et al., 1965; Cohen and Yielding, 1965). The intercalation of chloroquine seems to take place with double DNA, containing guanine; which also occurred with quinine and primaquine, but was not observed with mefloquine, another congener of the same quinine family (Allison et al., 1966; Davidson et al ., 1977)

Erythrocytes infected by plasmacytes quickly concentrate the drug as well as do present granulation of the malaria pigment that is formed while the parasite digests hemoglobin from erythrocytes of the infected host (Chou et al., 1980).

\section{Absorption, destination and excretion}

All the researches indicate that chloroquine is indeed absorbed by the gastrointestinal tract, very quickly, since less than $10 \%$ of the ingested dose is found in the feces of the host (Cotegiani, 2020). Virtually 55\% of the plasma substance is bound to nondiffuser and unidentified plasma constituents (Plowe, 2005).

Chloroquine elimination happens very slowly. Nevertheless, urine acidification is observed in the process. In the tissues however, it is deposited in great amounts which makes this drug very interesting for long term use when necessary. In 
animal models, chloroquine concentration is of 200 to 700 times higher than it is in the plasma, and is present in the spleen, kidneys, liver, lungs and also in tissues that contain melanin; also targeting lymphocytes. However, in the brain and in the spinal cord; the main representatives of the central nervous system, the contrary takes place, and it is observed only 10 to 30 times the plasma concentration (National Center for Biotechnology Information, 2019). Following its way to be excreted, chloroquine undergoes a notable transformation; for its main metabolite is desetilchloroquine, representing a quarter of the total material present in the urine; bidesetilchloroquine, a carboxylic acid derivative, as well as other still uncharacterized metabolic products have been found in small ones. In short: half of the byproducts found in the urine consists of unchanged chloroquine (National Center for Biotechnology Information, 2019).

\section{RNA viruses}

RNA viruses encode a specific enzyme that catalyzes RNA synthesis from an RNA template ( RNA-direct RNA synthesis), using much of the same mechanism of base pairing between the complementary strands employed during DNA replication or transcription of RNA from DNA. Trials conducted by Howard Temin in the beginning of the 1960s confirmed that their replication requires DNA synthesis, within the infected cells, conjecturing that RNA virus replicate via synthesis of a DNA intermediate: the provirus DNA. Temin and David Baltimore in the beginning of found that RNA tumor viruses contained an enzyme that was able to catalyze DNA synthesis from an RNA template. Now called reverse transcription, DNA synthesis from RNA was established as a form of information transfer in the biological systems (Temin, 1975). In this sense, reverse transcription is essential not only for the effective replication of RNA viruses, but also in at least two other broad aspects of molecular and cellular biology. Firstly, we might have in mind that reverse transcription is not restricted to viruses. It also takes place within the very cells, in the transposition of DNA sequences that happens from one chromosomal location to another. Secondly, enzymes that catalyze RNA-directed DNA synthesis (reverse transcriptases) can be used experimentally to generate DNA copies from any RNA molecule of a specific host. An excellent example about this template replication is the physiology of RNA viruses concerning their viral particles. It all begins when the host gets infected. A DNA copy of the RNA of the virus is produced by synthesis, via reverse transcription, and then integrated in the cell nucleus of the host, more specifically into chromosomal DNA in order to create a DNA provirus, which will provide the yield progeny RNA virus; constituting the basis of RNA virus pathology.

\section{Cellular alterations caused by chloroquine and hydroxychloroquine}

As has been reported above, the toxicity of chloroquine stimulated the search for new derivates to lessen the toxic effects, and all the researched accomplished led to the discovery of hydroxychloroquine. What makes hydroxychloroquine more clinically attractive when it involves virotic RNA infections is the fact that this altered drug acts on the cell machinery, reducing its metabolism. It changes the very cell, diminishing ribosomal activity inside the cytoplasm, jeopardizing the entrance of the virus, affecting also its replication and secretion, more specifically the production and liberation of the infective virotic particles.

Cell functioning mechanisms depend a lot on protein production to repair damages and for basic metabolic functions, such as phagocytosis and mitosis; the latter maybe the most important characteristic of the cells in general. DNA or RNA virus need the cell of the host to replicate and be unleashed in the bloodstream to infect others; which means that any therapy applied to breakdown the virus pathology should focus directly on the ribosomes; organelles responsible for protein production; being found scattered in the cytoplasm or stuck on the surface of the rough endoplasmic reticulum. Ribosomes are also found withing the mitochondrias, and are named in such situation as mitochondrial ribosomes. They bring together amino acids in order to 
form specific proteins depending on the cell need; by translating the genetic code transcribed into mRNA into an amino acid sequence. They use cellular accessory proteins such as soluble transfer RNAs, and it is necessary lots of metabolic energy to make the initiation, followed by elongation, and finally the termination of peptide synthesis.

Hydroxychloroquine therapy is directed to alter the cellular capacity to produce protein by altering the normal functions of the ribosomes. Once on the surface of the cell membrane, the virus has to be englobed to liberate its RNA envelope inside the cytoplasm to have it decoded by the ribosomes. The virotic genome is decoded into proteins to be transported to the chromosomes for replication. By the time ribosomal activity is decreased, all the basic functions of the cell in question is changed because of low protein production. This specific fact implies in the establishment of at least three barriers for virus survival. The first of them is a reduced cell capacity for endocytosis, jeopardizing the virus entrance to infect the cell. With the influence of hydroxychloroquine, ribosomes work insufficiently; but do not stop their functioning completely. Some virus manage to enter and replicate, but with difficulty or delay. Once within, the virus genome constituted of RNA fragments will be packed in the endosome, to produce non structural viral proteins.

The second barrier: replicase alteration, an enzyme that catalyzes the synthesis of a complementary RNA molecule using an RNA template. Replicase will allow the virus genome to be decoded and transported (DNA or RNA). In this sense, Hydroxychloroquine makes replication difficult to be accomplished, by inhibiting replicase. The third barrier: with the cell machinery altered, the secretory via is also affected for the liberation of the virotic infective particles into the blood stream. It is worth mentioning that all these chloroquine congeners are cheap drugs that have been on the scientific road for nearly 80 years, and therefore have their main effects and side-effects well known and described.

\section{Antiviral potential of chloroquine}

From the brink of the year 2000 there have been the outbreak of many epidemies beginning in China; more specifically respiratory syndromes such as MERS, H1N1 and SARS-CoV-1. This is probably due to alimentary habits of consuming many kinds of living animals such as pangolins, monkeys, camels and particularly bats. The evolutionary path developed by these animals made them so unique that virus that originate from them are usually totally unknown to other animals with traditional evolutive features, such as humans. SARS-CoV-1 was initially reported in Guangdone Province of China, in 2002, and immediately transmitted to more than 30 countries in the period of few months after its being initially reported.

On December $31^{\text {st }} 2019$, a much more dangerous coronavirus appeared in Wuhan, this time with unprecedent contaminating power: the new coronavirus disease which appeared in 2019 named COVID-19, which is still ongoing during the construction of this paper. The pandemic has up to this moment infected more than 18 million people and killed nearly four million patients, all over the continents. During the SARS-CoV-1 chloroquine had been initially also used with more or less success rate, Although it did not get too much attention, because the vaccine was reached short after, halting and containing the disease. COVID-19 is much more infective and aggressive, although sharing similarities with SARS-CoV-1. Therefore it was only natural that the scientific community thought of using hydroxychloroquine, as an experimental therapy.

French researchers were the first official scientists to adopt chloroquine treatment for COVID-19, but in combination with azithromycin with 26 patients, but with excellent results. During that period, a dramatic dose-dependent decrease in the number of virus antigen-positive could be noticed, just to have an idea, $0.1-1 \mu \mathrm{M}$ chloroquine was able to reduce infection by nearly 50\%; and up to $90-94 \%$ inhibition could be reached with 33-100 $\mu \mathrm{M}$ concentrations. When researchers analyzed these data, some of them speculated that, as chloroquine was a lisosomotropic agent, another common lysosomotropic agent such as $\mathrm{NH} 4 \mathrm{Cl}$ might lead to better results if associated with it. $\mathrm{NH} 4 \mathrm{Cl}$ seems to reduce pseudotypes viruses decorated with SARS$\mathrm{CoV}$ spike protein. Until the finalization of this paper, vaccination has been applied all over the world, and seems to be able to 
slow down the course of the pandemic, but as for what concerns effective therapies, all there is available are experimental trials still on observation.

There have been reports of a vast number of agents under clinical trials, but still no specific drug has been officially indicated. Patients who arrive at the hospitals with fever and mild symptoms are usually treated with analgesics and steroids, and in severe cases, ventilatory and renal support. However; there have been reports that hydroxychloroquine has shown good results in patients under intensive care therapy, although this information has not been accepted by WHO. The reason for choosing hydroxychloroquine was the previous positive reports concerning its use for SARS-CoV-1 with relative success.

Although politization has interfered with the experiments with this drug, there were some studies accomplished in in the southeast of Brazil, São Paulo, considered the epicenter of the COVID-19 pandemic in the country. Serious studies have been carried out with larger numbers of patients in order to establish a protocol for hydroxychloroquine to be implemented in the beginning of the symptoms, in association with azithromycin. This association is based on the capacity of hydroxychloroquine to jeopardize the virus entrance into the cytoplasm and disarrange ribosomal activity that would be necessary to cleave the RNA envelope of the virus, associated with azithromycin that decreases mitochondrial ribosomal activity, resulting in less production of energy by the cell. The idea of this therapy was that patients with light or mild symptoms would begin the therapy at home, without the need of hospital admission.

That fact that some drugs have been tested, alone or in combination, shows the need for an urgent therapy. The main schemes are shown below (Smith, 2020):

- Chloroquine - Initial clinical trials suggest a potential benefit when used alone, but lacks scientific evidence.

- Hydroxychloroquine - In vitro and clinical trials with low numbers of patients do suggest potential benefits, but still lacks scientific evidence.

- Azithromycin - Has been used in association with hydroxychloroquine and have been tested as a candidate for COVID-19 therapy, with positive results. More clinical trials are necessary to assess its action over mitochondrial ribosomes.

- Quaternary ammonium compound: $\mathrm{NH}_{4} \mathrm{Cl}$ (ammonium chloride). Compounds with proved antivirus activity

- Steroids (Prednisolone - $\Delta 1$-Cortisone); Cortisol (hydroxycortisone); Cortisone (11-Dehydrocortisol).

During the development of the pandemic across the world, the reemergence of the "old drugs" used for decades was not in vain. It happened because their clinical indications and side-effects are already known. More specifically, chloroquine and congeners have shown antiviral effects for a number of virotic infections. What is interesting about them is that they do not seem to act over the virus itself, but changing the mechanisms of the cell machinery. Their main mechanism rely on increasing lysosomal $\mathrm{pH}$ and cellular endorsement, impairing virus to be unleashed from them. (Savarino, 2003). With these effects on the cells, the virus is unable to replicate, or replicate insufficiently (Al-bari, 2017; Frederickson, 2002).

\section{Chloroquine and the QT interval}

The use of antibiotics are routine in respiratory infections. Therefore, the association with azithromycin was put into practice due to its broad spectrum able to indicate it treat many different sorts of infections, which may be caused by bacteria, such as pulmonary, skin, ear, eye and sexually transmitted infections. However, one of the main problems concerning chloroquine is that it increases the QT interval of the electrocardiogram. Some of the cardiac changes caused by chloroquine action is dose related and have been studied, especially the electrical impulses that are generated by myocytes. The 
transmission is usually well coordinated by these cardiac cells is a sequence of organized contractions necessary to pump the blood throughout the body. Nevertheless, one of the side-effects of chloroquine is the induction or prolonged QT interval, responsible for torsades de pointes which may be congenital or induced by drugs. Chloroquine may predispose the patients to arrhythmias by prolonging the repolarization of myocytes, which in some patients may cause sudden death by heart attack in $10 \%$ of patients (Haeusler, 2018). Therefore, it is mandatory that ECG monitoring be systematically incorporated in patients under prescription for chloroquine in the conventional treatment.

The mortality rate caused by SARS-CoV-2 varies around 3\% in the world, with slight variations in the different countries affected by it. The rate of course may be altered by social-economical situations, culture and tourism, but the fact is that the treatment offered to cure a disease must never be worse in rates than the illness itself. In this sense, Mercuro et al. (2020), in a cohort study accomplished in Boston with 90 patients concluded that the QT interval prolongation may be increased with the concomitant use with other drugs as well, such as diuretics and also azithromycin. Other study assessed the influence of hydroxychloroquine and chloroquine on the QT interval. They analyzed 46 rheumatic patients, 42 of them used chloroquine while 4 used hydroxychloroquine). Both groups applied a dosage of $7 \mathrm{mg} / \mathrm{kg}$ per day of hydroxychloroquine and $4 \mathrm{mg} / \mathrm{kg}$ per day of chloroquine). The results obtained showed that QTc interval prolongation could be observed in $17.39 \%$ of all the patients. With the exception of 1 patient, all the others repeated ECG and the return to the normal scores were observed. They concluded that chloroquine indeed prolonged the QT interval as an adverse effect (Rey, 2003); which seems to be the most dangerous effect of this class of drugs. (January and Riddle, 1989).

\section{Conclusion}

Chloroquine has been known in the scientific world since 1940 and was incorporated in the medical arsenal as an antimalarial agent. Their cellular action, however, made it cogitable for being used as anti-viral against SARS-CoV-2 associated with Azithromycin. This combination, although promising needs to be better researched and must be taken with due care and attention because of the cardiac implications caused by increased QT prolongation. It is mandatory that periodic ECGs be included in the protocols for the monitoring of the patients who make use of this drugs.

\section{References}

《柳叶刀披露首例新冠肺炎患者发病日期, 较官方通报早7天》. BJ News.

Al-Bari, M. A. (2017). "Targeting endosomal acidification by chloroquine analogs as a promising strategy for the treatment of emerging viral diseases". Pharmacology Research and Perspectives. 5 (1): e00293. doi:10.1002/prp2.293. PMC 5461643. PMID 28596841.

Allison, J. L., Brien, R. L. O’ \& Hahn, F.E. (1966). Nature of the Deoxy Ribonucleic Acidchloroquine complex. In Antimicrobial agents and chemotherapy (Sylverster, J.C; ed.) American Society for Microbiology, Ann. Arbor. Mich. Pp. 310-314. 10.1128/aac.5.3.310

Bagnall, A. The value of chloroquine in rheumatoid disease. A four-year study of continuous therapy. Can Med Assoc J, 1957, 77, $182-194$.

Berliner, R. W., Earle, D. P., Taggart, J. V., Zubrodder, S. T., Welch, W. J., Conan, N. J., Bauman, E., Scudder, S. T., \& Shannon, J. A. Studies on the chemotherapy of the human malarias. VI. The physiological disposition, antimalarial actifity, and toxicity of several derivatives of 4 -aminoquinoline. $J$. Clin.Invest. 1948, 27, 98-107.

Bruce-Chwatt, L. J. EmMalaria: Principles and Practice of Malariology;Wernsdorfer, W. H.; McGregor, I,eds.; Churchill Livingstone: Edinburgh, 1988, 159.

Carlson, J., Helmby, H., Hill, A., Brewster, D., Greenwood, B. \& Wahlgren, M. (1990). Human cerebral malaria: association with erytbrocyterosetting and lack of anti-rosetting antibodies. Lancet, 336, 1457-1460.

Cohen, S. N., \& Yielding.K. L. 1965. Inhibition of DNA and RNA polymerase reactions by chloroquine. Proc. Nat. Acad. Sci. U.S.A. 54:521-527

Chew, C. Y. et al. Hydroxychloroquine in dermatology: New perspectives on an old drug. The Australasian College of Dermatologists, n. 2 , 2019. https://revistas.unijui.edu.br/index.php/contextoesaude/article/download/10393/6369 
Cortegiani, A., Ingoglia, G., Ippolito, M., Giarratano, A., \& Einav S (2020). "A systematic review on the efficacy and safety of chloroquine for the treatment of COVID-19". Journal of Critical Care. doi:10.1016/j.jcrc.2020.03.005.

«Coronavirus disease (COVID-19) outbreak» . Organização Mundial da Saúde.

Davidson, M. W. Antimalarial action of quinoline methanolamines as mefloquine, quinacrine, chloroquine and quinine does not involve interaction with DNA, reported results from laboratory study. J. Med. Chem, 20 (9), 1117-1122 (1977).

Dubois, E. L. Antimalarials in the management of discoid and systemic lupus arythematosus. Semin Arthritis Rheum. 1978;8:3351.https://doi.org/10.1016/0049-0172(78)90033-1

Fern, Ken (2010-2020). "Cinchona officinalis - L." Plans for a Future.

Foye, W. O.; Lemke, T. L.; \& Williams, D. A.; Principles of Medicinal Chemistry, (4th ed.), Williams \& Wilkins: 1995.

Fredericksen, B. L., Wei, B. L., Yao, J., Luo, T., \& Garcia, J. V. (November 2002). "Inhibition of endosomal/lysosomal degradation increases the infectivity of human immunodeficiency virus". Journal of Virology. 76 (22): 11440-6. doi:10.1128/JVI.76.22.11440-11446.2002. PMC 136743. PMID 12388705.

Garnham, P. C. C. 1966. Malaria parasites and other haemosporidia. Blackwell Scientific Publications, Oxford, United Kingdom. Google Scholar.

Haeusler, I. L.; Chan, X. H. S.; Guérin, X. H. S.; Guérin, P. J.; \& White, N. J. The arrhythmogenic cardiotoxicity of the Quinoline and structurally related antimalarial drugs: A systematic review. BMC Med, 16(1), 200. 2018.

Inder, R. M. -Malaria; the design, use, and mode of action of chemotherapeutic agents. Dorchester, Scientechnica, Dorset, 1973.316 p.

Isaacson, D., Elgart, M., \& Turner, M. L. Antimalarials in dermatology. Int J Dermatol. 1982;21:379-95.

January, C., \& Riddle, J. (1989) Early after depolarizations: mechanism of induction and block. A role for L-type Ca2+ current. Circ Res64: 977-990 [PubMed] [Google Scholar]

Krafts, K., Hempelmann, E., \& Skórska-Stania, A (2012). "From methylene blue to chloroquine: a brief review of the development of an antimalarial therapy". Parasitology Research. 111 (1): 1-6.

National Center for Biotechnology Information, 2019. The United States National Library of Medicine. https://doi.org/10.1007/s00436-012-2886-x

Novel Coronavirus Pneumonia Emergency Response Epidemiology Team (February, 2020). «[The epidemiological characteristics of an outbreak of 2019 novel coronavirus diseases (COVID-19) in China]». Zhonghua Liu Xing Bing XueZaZhi=ZhonghuaLiuxingbingxueZazhi (emchinês). 41 (2): $145-151$. 10.3760/cma.j.issn.0254-6450.2020.02.003

Organizacion Mundial De La Salud -Terminologiadeipaludismo y de Iaerradicacióndeipaludismo. 1964.p.122.

Orolkovas, A. -Mecanismo de ação dos antimaláricos. Rev. bras. Clin. Terap., , 4 (5): 183-186,1975.

Peters, W. -Chemotherapy and drug resistance in malaria. Ipswich, Academic Press, 1970. 876 p.

Pinder, R. M. -Malaria; the design, use, and mode of action of chemotherapeutic agents. Dorchester, Scientechnica, Dorset, $1973.316 \mathrm{p}$

Plowe, C. V. (2005). "Antimalarial drug resistance in Africa: strategies for monitoring and deterrence". Malaria: Drugs, Disease and Post-genomic Biology. Current Topics in Microbiology and Immunology. 295. pp. 55-79. doi:10.1007/3-540-29088-5_3. ISBN 3-540-25363-7. PMID 16265887.

Powell, S. J. Therapy of amebiasis. Bull NY Acad Med 47:469-477, 1971

Rainsford, K. D., Parke, A. L., Clifford-Rashotte, M. \& Kean, W. F. Therapy and pharmacological properties of hydroxychloroquine and chloroquine in treatment of systemic lupus erythematosus, rheumatoid arthritis and related diseases. Inflammopharmacology. 2015;23(5):231-69.

Rey, L. D. ECT QT interval prolongation in reumathic patients using antimalarial drugs. Rev. Bras. REumatol. (on line). 2003. Vol.43, n.5, pp.275-278. ISSN 0482-5004. https://doi.org/10.1590/S0482-5004200300500003.

Rockwell, D A. Psychiatric complications with chloroquine and quinacrine. Am J Psychiatry. 1968;124(9):1257-60.

Rowe, A., Obiero, J., Newbold, C. \& Marsh, K. (1995). Plasmedium falciparum rosetting 1s associated with malaria severity in Kenya. Infection and Immunity, 63,2323-2326.

Rynes, R. I. Antimalarial drugs in the treatment of rheumatological diseases. Br J Rheumatol. 1997;36(7):799-805. Comment in: Br J Rheumatol. 1998;37(5):580.

Savarino, A., Boelaert, J. R., Cassone, A, Majori, G, \& Cauda R (November 2003). "Effects of chloroquine on viral infections: an old drug against today's diseases?". The Lancet. Infectious Diseases. 3 (11): 722-7.https://doi.org/10.1016/S1473-3099(03)00806-5

Schellenberg, K. A., \& Coatney, G. R. Biochem, Pharmacol. 6, 143 (1960).

Smith, T., Bushek, J., \& Prosser, T. COVID-19 Drug therapy - Potential Options. Elsevier.

«Statement on the second meeting of the International Health Regulations (2005) Emergency Committee regarding the outbreak of novel coronavirus (2019$n \mathrm{noV}) »$. OMS. 
Research, Society and Development, v. 10, n. 10, e486101018220, 2021

(CC BY 4.0) | ISSN 2525-3409 | DOI: http://dx.doi.org/10.33448/rsd-v10i10.18220

Rowe, A., Obiero, J., Newbold, C. Chou, A. C., \& Fitch, C. D. (1980) Hemolysis of mouse erythrocytes by ferriprotoporphyrin IX and chloroquine: Chemotherapeutic implications. J Clin Invest 66:856-858. https://doi.org/10.1016/0140-6736(90)93174-N

Steck, E. A. -Chemotherapy of malaria. In: The chemotherapy of protozoan diseases. (Washington). Walter Reed Army I nstitute of Research, (1971). Vol. 3, Capo2 3. 376p.

Temin, H. M. The DNA provirus hypothesis-The Establishment and Implications of RNA-directed DNA Synthesis. Physiology or Medicine. University of Wisconsin, Madison, Wisconsin, USA. 1975.

Udomsangpetch, R., Thanikkul, K., Pukrittayakamee, S. \& White, N. J. (1995). Rosette formation by Phmodium\&ax. Transactions of the Royal Society of Tropical Medicine and Hygiene, 89, 635-637.

Verbeeck, R. K.; Junginger, H. E.; Midha, K. K.; Shah, V. P.; \& Barends, D. M. Biowaiver Monographs for Immediate Release Solid Oral Dosage Forms Based on Biopharmaceutics Classification System (BCS) Literature Data: Chloroquine Phosphate, Chloroquine Sulfate, and Chloroquine Hydrochloride. J Pharm Sci 94:1389-1395, 2005.

W. Sneader: Drug Discovery. a history. wiley, https://doi.org/10.1016/0035-9203(95)90422-0

Wallace, D. J. Antimalarial agents and lupus. Rheum Dis Clin North Am. 1994; 20(1): 243-63. Review.

White, N. J. (2008). Plasmodium knowlesi: the fifth human malaria parasite. Clin. Infect. Dis. 46:172-173. CrossRefPubMedWeb of ScienceGoogle Scholar. https://doi.org/10.1016/S0889-857X(21)00233-7

Zhang, T. et al. Clinical trials for the treatment of Coronavírus disease 2019 (COVID-19): A rapid response to urgent need. Science China life Sciences, n. 12, https://revistas.unijui.edu.br/index.php/contextoesaude/article/download/10393/6369 